\title{
Karta Praw Podatnika \\ W POLSKIM SYSTEMIE PODATKOWYM W ŚWIETLE DOŚWIADCZEŃ ZAGRANICZNYCH
}

Streszczenie. Celem artykułu nie jest omówienie formy i treści Karty Praw Podatnika w poszczególnych państwach, lecz dokonanie pewnych uogólnień na podstawie analizy rozwiązań funkcjonujących $\mathrm{w}$ różnych systemach prawnych oraz proponowanych w ramach międzynarodowych inicjatyw mających na celu upowszechnienie i ujednolicenie koncepcji Karty. Uogólnienia te będą podstawą do sformułowania w zakończeniu artykułu wstępnych wniosków dotyczących roli, formy i treści, jaką mogłaby przybrać Karta w warunkach polskiego systemu podatkowego.

Słowa kluczowe: prawa podatnika, ochrona praw podatnika, Karta Praw Podatnika

\section{WPROWADZENIE}

Karta Praw Podatnika (dalej: Karta) jest instrumentem funkcjonującym w wielu państwach, ale charakteryzującym się różną formą, treścią i skutecznością. Kartę wprowadza się, by wzmocnić ochronę praw podatnika przez ich skonsolidowanie w jednym dokumencie, usystematyzowanie i wyrażenie w sposób możliwie zrozumiały. Karta może poprawić relacje między podatnikami i organami podatkowymi, przejrzyście kształtując podstawowe „reguły gry”, a także zwiększyć u podatników poczucie bezpieczeństwa prawnego i akceptację systemu podatkowego, co z kolei może

* Adiunkt w Katedrze Prawa Podatkowego na Wydziale Prawa i Administracji Uniwersytetu Łódzkiego, e-mail: msek@wpia.uni.lodz.pl 
prowadzić do zwiększenia poziomu dobrowolnej realizacji podatku. Już samo zwiększanie świadomości praw podatnika wśród podatników oraz administracji podatkowej może prowadzić do podniesienia poziomu praktycznej ochrony praw podatnika.

Celem artykułu nie jest omówienie formy i treści Karty w poszczególnych państwach, lecz dokonanie pewnych uogólnień na podstawie analizy rozwiązań funkcjonujących $\mathrm{w}$ różnych systemach prawnych oraz proponowanych w ramach międzynarodowych inicjatyw mających na celu upowszechnienie i ujednolicenie koncepcji Karty. Uogólnienia te będą podstawą do sformułowania w zakończeniu artykułu wstępnych wniosków dotyczących roli, formy i treści, jaką mogłaby przybrać Karta w warunkach polskiego systemu podatkowego.

\section{Karta Praw Podatnika - POJĘCiE}

Karta Praw Podatnika to w uproszczeniu tekst normatywny lub deklaratywny, w którym w zwięzły sposób określone są podstawowe prawa, a często i obowiązki podatników, którym odpowiadają obowiązki i uprawnienia organów podatkowych. P. Baker definiuje Kartę jako „krótki, przystępny komunikat dotyczący podstawowych praw (i obowiązków) podatników w stosunkach z administracją podatkową" ${ }^{\text {. }}$ M. Cadesky, I. Hayes i D. Russell określają Kartę jako „próbę streszczenia i wyjaśnienia, w prostym języku, praw i obowiązków podatnika dotyczących jego spraw podatkowych, w celu uczynienia tej informacji szeroko dostępną i zrozumiałą"2.

We współczesnych systemach podatkowych występują Karty o różnym charakterze, pochodzeniu, mocy wiążącej, zakresie treściowym i stopniu szczegółowości, o czym będzie mowa w dalszej części artykułu. W tym miejscu warto jedynie podkreślić, że Karty mogą mieć postać przepisów prawa powszechnie obowiązującego, gdy pochodzą od władzy ustawodawczej, lub jednostronnej deklaracji administracji podatkowej. Karty najczęściej przyjmują formę odrębnych dokumentów (normatywnych lub deklaratywnych). Niekiedy za Kartę uznaje się dostatecznie wyodrębnioną

${ }^{1}$ P. Baker, Taxpayers' Charters and a Taxpayers' Charter for Europe, [w:] Protection of Taxpayer's Rights. European, International and Domestic Tax Law Perspective, red. W. Nykiel, M. Sęk, Wolters Kluwer Polska, Warszawa 2009, s. 132.

${ }^{2}$ M. Cadesky, I. Hayes, D. Russell, A Model Taxpayer Charter. Preliminary Report. Towards Greater Fairness in Taxation, AOTCA, CFE, STEP, London 2013, s. 162. 
część ogólnych ustaw podatkowych, skupiającą przepisy dotyczące podstawowych praw (i obowiązków) podatników.

Ważnym wyróżnikiem Karty na tle innych tekstów wyrażających prawa (i obowiązki) podatnika powinna być jej szeroko pojęta dostępność zarówno dla podatnika i jego pełnomocnika, jak i dla organów podatkowych, obejmująca sposób sformułowania i publikacji zapewniający łatwość zapoznania się z Kartą i zrozumienia jej treści ${ }^{3}$.

\section{Karta Praw Podatnika Jako międzynarodowy standard}

Posiadanie Karty Praw Podatnika jest międzynarodowym, uznanym standardem. Karta jest instytucją znaną wielu systemom podatkowym. W licznych państwach, które obecnie nie posiadają Karty, przewiduje się jej wprowadzenie (np. Brazylia - w zakresie Karty federalnej ${ }^{4}$, Japonia ${ }^{5}$ ), albo przynajmniej wskazuje na taką potrzebę (np. Wenezuela ${ }^{6}$ ). Są jednak państwa, w których mimo braku Karty poziom ochrony praw podatnika jest w praktyce oceniany jako bardzo wysoki (np. Dania ${ }^{7}$, Singapur ${ }^{8}$ ). Dostrzegają to również M. Cadesky, I. Hayes i D. Russell, którzy ponadto zauważają, że prawa podatników w państwach nieposiadających Karty mogą być bardzo podobne do tych przysługujących podatnikom w państwach, które Kartę wprowadziły ${ }^{9}$. Autorzy ci spostrzegli jednak, że posiadanie przez poszczególne państwa Kart może znacznie ułatwić porównanie ich systemów podatkowych pod kątem ich przyjazności dla podatnika ${ }^{10}$. Karty zwiększają przejrzystość systemu podatkowego i jako przejaw podążania za najlepszymi praktykami mogą być elementem przewagi konkurencyjnej danej jurysdykcji podatkowej nad innymi jurysdykcjami ${ }^{11}$.

Karta Praw Podatnika to relatywnie nowa instytucja prawa podatkowego. Istnieje spór, czy pierwszą Kartą była ta ogólna wprowadzona

${ }^{3}$ Zob. P. Baker, Taxpayers' Charters..., s. 132.

${ }^{4}$ The Practical Protection of Taxpayers' Fundamental Rights, red. P. Baker, P. Pistone, Cahiers de droit fiscal international vol. 100b, Sdu Uitgevers, Hague 2015, s. 165.

${ }^{5}$ M. Cadesky, I. Hayes, D. Russell, A Model Taxpayer Charter..., s. 74.

${ }^{6}$ The Practical Protection of Taxpayers'..., s. 890.

${ }^{7}$ Ibidem, s. 283-284.

${ }^{8}$ Ibidem, s. 677-678.

${ }^{9}$ Zob. M. Cadesky, I. Hayes, D. Russell, A Model Taxpayer Charter..., s. 162.

${ }^{10}$ Zob. ibidem.

${ }^{11}$ Ibidem, s. 198. 
w Zjednoczonym Królestwie w 1986 r., czy może za pierwszą Kartę należy uznać francuski dokument dotyczący praw podatnika w toku kontroli podatkowej z $1975 \mathrm{r}^{12}$

Już w 1990 r. Organizacja Współpracy Gospodarczej i Rozwoju (Organization for Economic Cooperation and Development - OECD) w swoim raporcie dotyczącym praw i obowiązków podatnika ${ }^{13}$ rekomendowała państwom członkowskim posiadanie Karty, a w aktualizacji raportu z 2003 r. $^{14}$ wskazano, że 2/3 państw członkowskich OECD posiada Kartę.

$\mathrm{Na}$ potrzeby międzynarodowego programu badawczego poświęconego praktycznej ochronie praw podatnika, prowadzonego z inicjatywy Międzynarodowego Stowarzyszenia Podatkowego (International Fiscal Association - IFA) ${ }^{15}$, Kartę zaliczono do ram instytucjonalnych (ang. institutional framework) ochrony praw podatnika, obok takich instytucji jak rzecznik praw podatnika.

Dobrą praktyką, międzynarodowym dobrym standardem, jest też obowiązek przekazania podatnikowi przed rozpoczęciem kontroli zestawienia praw i obowiązków, np. we Francji przekazuje się egzemplarz Karty Praw i Obowiązków Kontrolowanego Podatnika ${ }^{16}$.

W skali międzynarodowej podejmowano pewne inicjatywy mające na celu ujednolicenie standardów w zakresie Kart. Należy tu wskazać unijny projekt dotyczący praw i obowiązków podatników, który zaowocował opublikowaniem w 2016 r. Wytycznych dotyczących wzoru Kodeksu podatników Unii Europejskiej ${ }^{17}$ (Guidelines for a Model for a European Taxpayers' Code) ${ }^{18}$ oraz projekt Modelowej Karty Podatnika (A Model Taxpayer Charter), prowadzony pod auspicjami trzech międzynarodowych organizacji skupiających doradców podatkowych i majątkowych: Stowarzyszenia Doradców Podatkowych Azji i Oceanii (Asia Oceania Tax Consultants' Association - AOTCA), Europejskiej Konfederacji Podatkowej (Confédération Fiscale Européenne - CFE) i Towarzystwa Praktyków Powiernictwa i Nieruchomości (Society of

12 Zob. P. Baker, Taxpayers' Charters..., s. 132.

${ }^{13}$ OECD, Taxpayers' Rights and Obligations: A survey of the legal situation in OECD countries, Paris 1990.

${ }^{14}$ OECD, GAP002 Taxpayers' Rights and Obligations - Practice Note, Paris 2003.

${ }^{15}$ Zob. The Practical Protection of Taxpayers'...

${ }^{16}$ Zob. ibidem, s. 353, 368.

${ }^{17} \mathrm{~W}$ języku polskim zob. https://ec.europa.eu/taxation_customs/sites/taxation/files/ guidelines_for_a_model_for_a_european_taxpayers_code_pl.pdf (dostęp: 7.11.2017).

${ }^{18} \mathrm{~W}$ języku angielskim zob. https://ec.europa.eu/taxation_customs/sites/taxation/files/guidelines_for_a_model_for_a_european_taxpayers_code_en.pdf (dostęp: 7.11.2017). 
Trust and Estate Practitioners - STEP), który w 2013 r. zaowocował obszerną monografią zawierającą propozycję modelowej Karty ${ }^{19}$.

Treść Modelowej Karty Podatnika, której autorami są M. Cadesky, I. Hayes i D. Russell, stanowi efekt analizy praw i obowiązków podatnika w 37 państwach członkowskich OECD, reprezentujących ponad 73\% światowego $\mathrm{PKB}^{20}$. W Modelowej Karcie wymieniono jedynie te prawa i obowiązki, które obowiązywały przynajmniej w jednej z poddanych analizie jurysdykcji podatkowych ${ }^{21}$. Twórcy Modelowej Karty uprzednio zidentyfikowali też wady regulacji praw podatnika w badanych państwach, dostrzegając m.in., że zapisy zawarte w Kartach niemających formy ustaw pozbawione są mocy prawnej i w rezultacie są ignorowane przez podatników, doradców podatkowych i organy podatkowe; takie Karty praw podatnika są tylko pewną deklaracją wskazującą, jak administracja podatkowa zamierza działać w danych warunkach, skoncentrowaną na kwestii egzekucji należności podatkowych i mającą służyć przede wszystkim tym celom, a więc niezbyt użyteczną dla podatników; administracja podatkowa nie ponosi odpowiedzialności wobec podatników za naruszenie postanowień Karty ${ }^{22}$. Stąd wniosek, że Karta powinna mieć moc prawa powszechnie obowiązującego $^{23}$. Twórcy Modelowej Karty przyjęli też założenie, że prawa powinny być określone w Karcie w sposób kompleksowy i szczegółowy ${ }^{24}$, co bezpośrednio przełożyło się na objętość Modelowej Karty, wynoszącą ponad trzydzieści stron ${ }^{25}$. Tekst Modelowej Karty został podzielony na 34 artykuły, które podlegają dalszemu podziałowi redakcyjnemu i zostały zaopatrzone w dość obszerne, klarownie sformułowane wyjaśnienia, często o bardzo praktycznym charakterze.

W Modelowej Karcie zawarto wiele podstawowych praw dotyczących etapu składania deklaracji, postępowania kontrolnego, wymiarowego i odwoławczego, a także takich zagadnień jak ciężar dowodu i rola profesjonalnych pełnomocników. Uregulowano też m.in. prawo do pomocy, prawo do

${ }^{19}$ Mowa o przywoływanej już pracy M. Cadesky, I. Hayes, D. Russell, A Model Taxpayer Charter... Sama Karta, w najnowszej wersji, dostępna jest w Internecie, http:// www.taxpayercharter.com/charter.asp?id=16 (dostęp: 28.10.2019).

${ }^{20}$ M. Cadesky, I. Hayes, D. Russell, A Model Taxpayer Charter..., s. 19.

${ }^{21}$ Ibidem, s. 20.

${ }^{22}$ Ibidem, s. 20, 33.

${ }^{23}$ Ibidem, s. 26.

${ }^{24}$ Ibidem.

${ }^{25}$ Zob. ibidem, s. 35-71. 
otrzymania informacji w formie interpretacji indywidualnych i ogólnych, dokumentację do celów podatkowych i poufność danych dotyczących podatnika, odsetki, kary i dobrowolne ujawnienie (ang. voluntary disclosure), a także odniesiono się do takich kwestii, jak podwójne opodatkowanie i jego eliminacja oraz prawa podatnika a unikanie i uchylanie się od opodatkowania i nieuczciwość. Twórcy Modelowej Karty dostrzegli też, że regulacja praw podatnika w poszczególnych państwach często nie obejmuje standardów dotyczących tworzenia prawa podatkowego i procedur konsultacji projektów aktów prawnych ${ }^{26}$, którym w Modelowej Karcie poświęcono dużo uwagi.

W Wytycznych dotyczacych wzoru Kodeksu podatników Unii Europejskiej podkreślono, że obowiązujące w państwach członkowskich kodeksy i karty podatników różnią się zakresem stosowania i treścią ${ }^{27}$, a opracowanie wspólnego wzoru może m.in. zapewnić równe traktowanie wszystkich podatników i wyższy poziom pewności prawa, zwiększyć przejrzystość, a także ograniczyć liczbę sporów ${ }^{28}$. Jak wskazano w Wytycznych, Kodeks jest dokumentem niewiążącym, pewnym wzorem do naśladowania, do którego państwa członkowskie mogą dodawać elementy lub dostosowania, tak by odpowiadał on krajowym potrzebom i okolicznościom ${ }^{29}$. Postanowienia Kodeksu z założenia mają na celu „zapewnienie równowagi między prawami i obowiązkami podatników i administracji podatkowych"30. Kodeks oparto na „podstawowych zasadach ogólnych i na najlepszych praktykach obowiązujących w państwach członkowskich, które uznano za przydatne do celów wzmocnienia współpracy i zaufania między administracjami podatkowymi a podatnikami, zapewnienia większej przejrzystości praw i obowiązków tych dwóch podmiotów oraz zachęcania administracji podatkowych do stosowania metod w większym stopniu ukierunkowanych na usługi" 31 .

Postanowienia Kodeksu można podzielić na dwie części: zasady ogólne i najlepsze praktyki określone w rozdziale trzecim Wytycznych oraz wskazówki co do dalszego rozwoju dobrych praktyk i nowe pomysły na

${ }^{26}$ Ibidem, s. 20, 33.

${ }^{27}$ Zob. Komisja Europejska, Wytyczne dotyczące wzoru Kodeksu podatników Unii Europejskiej, Bruksela 2016, s. 6, https://ec.europa.eu/taxation_customs/sites/taxation/files/guidelines_for_a_model_for_a_european_taxpayers_code_pl.pdf (dostęp: 7.11.2017).

${ }^{28}$ Ibidem, s. 7.

${ }^{29}$ Ibidem, s. 1, 5.

${ }^{30}$ Ibidem, s. 4.

${ }^{31}$ Ibidem. 
przyszłość, określone w rozdziale czwartym ${ }^{32}$. To właśnie rozdział trzeci odpowiada treściowo instytucji Karty Praw Podatnika.

W Kodeksie do zasad ogólnych zaliczono: legalność i pewność prawa, poszanowanie prawa, niedyskryminację i równość podatników, uprzejmość i poszanowanie, bezstronność i niezależność, tajemnicę podatkową i ochronę danych, prywatność, przedstawicielstwo, a także - co zasługuje na szczególną uwagę - domniemanie uczciwości ${ }^{33}$. W części poświęconej najlepszym praktykom wymieniono i wyjaśniono zagadnienia $\mathrm{z}$ zakresu współpracy (przekazanie podatnikom informacji i wytycznych, usługi świadczone na rzecz podatników, kluczowe standardy usług, interpretacje o charakterze ogólnym, interpretacje indywidualne), procedur (zeznania podatkowe, wymiar podatków, proces kontroli, płatności i windykacja, dobrowolne ujawnianie, sankcje) i rozstrzygania (wewnętrzne postępowanie odwoławcze, rozpatrzenie sprawy przez sąd lub trybunał, prawo do składania skarg) ${ }^{34}$. Poszczególne kwestie zostały określone w formule tego, czego mogą oczekiwać podatnicy i czego oczekuje administracja podatkowa ${ }^{35}$.

Te międzynarodowe inicjatywy należy uznać za bardzo cenne, szczególnie jeśli ich rezultat uznamy za pewien dobry wzorzec dla prawodawców czy administracji krajowych rozważających wprowadzenie Karty bądź ulepszenie Karty już istniejącej. Niemniej forma, zawartość, treść Karty powinna być zindywidualizowana, to znaczy dostosowana do stopnia rozwoju systemu podatkowego danego państwa czy - w szerszym kontekście - rzeczywistości społeczno-politycznej i ogólnego poziomu kultury administrowania w danym państwie, w tym poziomu świadomości organów podatkowych i podatników oraz „temperatury” ich wzajemnych relacji. Zagadnienia, które w jednym państwie wymagają bezwzględnie regulacji, $\mathrm{w}$ innych państwach mogą być naturalnym elementem relacji na linii podatnik - organ podatkowy ${ }^{36}$. Innymi słowy, to, o czym w jednym państwie trzeba organom podatkowym lub podatnikom przypominać, $\mathrm{w}$ innym państwie może być oczywistością.

Zarówno twórcy Modelowej Karty Podatnika, jak i Wytycznych dotyczacych wzoru Kodeksu podatników Unii Europejskiej dostrzegli, że nie

\footnotetext{
${ }^{32}$ Ibidem, s. 5 .

${ }^{33}$ Zob. ibidem, s. 8-11.

${ }^{34}$ Zob. ibidem, s. 11-18.

${ }^{35}$ Zob. ibidem.

${ }^{36}$ Zob. np. Singapur, gdzie kluczową rolę odgrywa etos i profesjonalizm urzędniczy (The Practical Protection of Taxpayers'..., s. 677-678).
} 
wszystkie proponowane przez nich postanowienia będą odpowiednie dla każdej jurysdykcji podatkowej oraz że mogą być konieczne dostosowania lub uzupełnienia, każde bowiem państwo, konstruując swoją Kartę, powinno uwzględnić własne założenia, otoczenie legislacyjne, kulturę prawną i praktyki administracyjne ${ }^{37}$.

\section{Funkcja Karty Praw Podatnika}

W doktrynie wskazuje się na wieloletni trend wzrostu obowiązków podatników, przy jednoczesnej stagnacji w zakresie praw podatników ${ }^{38}$. Jednocześnie zauważa się, że dobrze funkcjonować może wyłącznie taki system podatkowy, który w ocenie podatników i ich pełnomocników jest sprawiedliwy, słuszny ${ }^{39}$. Tylko taki system zachęca do dobrowolnej zapłaty podatków (ang. voluntary compliance). Jednym $\mathrm{z}$ instrumentów równoważenia systemu, poprawiania społecznej percepcji systemu, jest właśnie Karta Praw Podatnika. Konstruując Kartę, trzeba dobrze wyważyć prawa i obowiązki podatników, interes podatników i interes wierzyciela podatkowego.

Podstawowym założeniem Karty powinno być domniemanie uczciwości podatnika, który działa w dobrej wierze i dochowuje należytej staranności w wywiązywaniu się ze swoich obowiązków wobec państwa. W obliczu coraz bardziej skomplikowanej rzeczywistości gospodarczej i regulacji podatkowej podatnik powinien mieć zagwarantowane, że nie poniesie kary za błąd popełniony mimo dochowania należytej staranności ${ }^{40}$. To element budowania poczucia sprawiedliwości, wzajemnego zaufania między podatnikami i administracją podatkową, a w rezultacie zwiększania poziomu dobrowolnej realizacji podatku. W literaturze zauważono, że Karta powoduje, iż „reguły gry stają się bardziej przejrzyste” ${ }^{41}$.

M. Cadesky, I. Hayes i D. Russell, twórcy Modelu Karty Podatnika, stwierdzili, że „celem Karty jest wzmocnienie relacji wzajemnego zaufania, szacunku i odpowiedzialności między podatnikami i państwem w zakresie obowiązków podatników wobec państwa i praw podatnika wobec

${ }^{37}$ Zob. M. Cadesky, I. Hayes, D. Russell, A Model Taxpayer Charter..., s. 162; Komisja Europejska, Wytyczne..., s. 1, 5.

${ }^{38}$ M. Cadesky, I. Hayes, D. Russell, A Model Taxpayer Charte..., s. 19.

${ }^{39}$ Ibidem, s. 18.

${ }^{40}$ Ibidem, s. 24.

${ }^{41}$ Zob. wypowiedź sprawozdawcy litewskiego [w:] ibidem, s. 152. 
państwa; skodyfikowanie obowiązków administracji podatkowej, i przez to zredukowanie kosztów przestrzegania przepisów, podniesienie jakości i efektywności dobrowolnej zapłaty podatku [ang. willing compliance] i zapewnienie wszystkim podatnikom równego traktowania bez uprzedzeń i preferencji"42.

Wydaje się, że podstawowym zadaniem Karty nie powinno być przyznanie podatnikom danych praw, bo te powinny raczej wynikać z konstytucji, zasady demokratycznego państwa prawa, a także uregulowań proceduralnego i materialnego prawa podatkowego. Nie oznacza to, że Karty nie mogą nieść nowej treści normatywnej. Karta w żadnym razie nie może ograniczać praw podatnika w stosunku do tych już przyznanych innymi przepisami czy wynikających z praktyki orzeczniczej ${ }^{43}$, stanowić kroku wstecz w zakresie praw podatnika. Karta może natomiast zwiększać zakres ochrony przysługującej podatnikom, a także przystępnie wyjaśniać treść już posiadanych przez nich praw ${ }^{44}$.

Nawet jeśli Karty powtarzają jedynie prawa, które wynikają już z innych przepisów, nie stanowią superfluum ustawowego czy przejawu inflacji prawa $^{45}$. Pełnią bowiem wówczas ważną rolę porządkującą, wzmacniającą oraz edukacyjną. Jak zauważa P. Baker, „nie ma nic złego w sytuacji, gdy te same prawa (i obowiązki) są określone w karcie podatnika i w innych, bardziej technicznych aktach prawa. Są to różne sposoby komunikowania tych praw i obowiązków"46.

Karta o charakterze normatywnym, nawet powtarzająca jedynie posiadane już przez podatnika prawa, wzmacnia ochronę tych praw poprzez usystematyzowanie ich $\mathrm{w}$ formie zasad systemu prawa podatkowego, to jest norm zawartych bezpośrednio w prawie pozytywnym i cechujących się szczególną doniosłością dla systemu prawa podatkowego jako całości, poszczególnych jego części i instytucji ${ }^{47}$. Normy zapisane w takiej Karcie,

${ }^{42}$ Ibidem, s. 21-22.

43 Ibidem, s. 35.

${ }^{44}$ Ibidem.

${ }^{45}$ Superfluum występuje, gdy ta sama kwestia jest uregulowana w kilku przepisach, gdy dochodzi do powtórzenia, dublowania treści normatywnej innych przepisów. Inflacja prawa to nadmiar przepisów, które tracą rzeczywisty wpływ na stosunki społeczne.

${ }^{46}$ P. Baker, Taxpayers' Charters..., s. 131.

${ }^{47}$ Zob. sformułowane przez J. Wróblewskiego pojęcie zasady prawa („zasady systemu prawa bądź jego części”) jako normy o szczególnej doniosłości (J. Wróblewski, Sądowe stosowanie prawa, PWN, Warszawa 1972, s. 131), która jest zawarta bezpośrednio w prawie pozytywnym lub jest logiczną konsekwencją norm lub grupy norm prawa pozytywnego 
z istoty swej bardziej ogólne, podlegają uszczegółowieniu w innych ustawach podatkowych. Są stosowane łącznie z innymi normami albo bezpośrednio i samodzielnie. Normy te stanowią też kontekst interpretacyjny dla innych przepisów prawa podatkowego.

Karty stanowią kompendium zasad, na jakich mają kształtować się wzajemne relacje między podatnikami a organami podatkowymi. Karta poprawia sytuację podatników również pośrednio, przez oddziaływanie na świadomość podatników i administracji podatkowej ${ }^{48}$. Nawet sceptyczni przedstawiciele doktryny przyznają, że „karta przypadkowo spowodowała poprawę $\mathrm{w}$ zakresie praw podatnika, na przykład przez podniesienie świadomości społecznej tych praw, a wśród administracji podatkowej - świadomości potrzeby przestrzegania tych praw" ${ }^{49}$. Nawet jeśli więc Karta nie niesie nowej treści normatywnej, możliwość jej oddziaływania na stan świadomości podatników i administracji podatkowej sama w sobie jest argumentem przemawiającym za wprowadzeniem Karty.

Karta odgrywa ważną rolę edukacyjną, bo nie każdy podatnik ma świadomość obowiązywania takich aktów prawnych, jak ordynacje lub kodeksy podatkowe, czy też ma okazję i chęć zapoznać się z zawartymi w nich przepisami, szczególnie biorąc pod uwagę często dużą objętość i hermetyczny język tych aktów. Karta ma znacznie większy potencjał dotarcia do podatnika, szczególnie jeśli administracja podatkowa będzie miała obowiązek przekazywać egzemplarz Karty podatnikowi przed przystąpieniem do kontroli czy przy wszczęciu postępowania podatkowego.

Wprowadzenie Karty jako jednolitego dokumentu może też być istotnym potwierdzeniem intencji prawodawcy, by rzeczywiście efektywnie chronić prawa podatnika.

(J. Wróblewski, Prawo obowiązujące a „ogólne zasady prawa”, „Zeszyty Naukowe Uniwersytetu Łódzkiego. Nauki Humanistyczno-Społeczne. Seria I" 1965, z. 42, s. 19, 21; K. Opałek, J. Wróblewski, Zagadnienia teorii prawa, PWN, Warszawa 1969, s. 249). Od tak rozumianych „zasad systemu prawa” J. Wróblewski odróżnia „postulaty systemu prawa", czyli reguły niebędące normami prawa pozytywnego (ani ich konsekwencjami), które mają charakter „ogólnych zasad prawa”, ale zasadami prawa nie są (J. Wróblewski, Prawo obowiązujące..., s. 18, 21).

${ }^{48}$ Zob. The Practical Protection of Taxpayers'..., s. 117.

${ }^{49} \mathrm{~J}$. Bevacqua, Redressing the Imbalance: Challenging the Effectiveness of the Australian Taxpayers' Charter, „Australian Tax Forum” 2013, no. 28, s. 377, 382, cyt. za: The Practical Protection of Taxpayers'..., s. 117. 
Funkcjonujące Karty można klasyfikować według kilku istotnych kryteriów.

Ze względu na kryterium charakteru prawnego czy mocy prawnej można wyróżnić Karty, które stanowią akty prawa powszechnie obowiązującego (np. Meksyk ${ }^{50}$, Włochy ${ }^{51}$ ), oraz Karty, które są jedynie pewnymi deklaracjami bez mocy wiążącej (np. Australia ${ }^{52}$, Izrael ${ }^{53}$, Kanada ${ }^{54}$, Turcja $^{55}$ ). Klasyfikacja ta bezpośrednio wiąże się też z klasyfikacją według kryterium podmiotu, który Kartę ustanowił. Według tego kryterium można dokonać podziału na Karty pochodzące od władzy ustawodawczej (parlamentu), przybierające postać przepisów powszechnie obowiązujących, oraz Karty pochodzące od władzy wykonawczej (administracji podatkowej), przybierające postać niewiążących deklaracji, broszur informacyjnych czy mniej lub bardziej wiążących wewnętrznych regulaminów. Niekiedy Karty mają nawet postać interpretacji ogólnych ${ }^{56}$.

Zdarza się także, że normy ustawowe nakładają na administrację podatkową obowiązek opracowania, ogłoszenia i przekazywania podatnikom Karty Praw Podatnika, formułując również pewne wytyczne odnośnie do treści tego dokumentu, jego obowiązkowej zawartości (np. Francja ${ }^{57}$, Korea Południowa ${ }^{58}$, Stany Zjednoczone ${ }^{59}$, Zjednoczone Królestwo ${ }^{60}$ ). W USA pierwsza ustawa określana jako Karta Praw Podatnika została przyjęta przez Kongres już w 1988 r. i wprowadziła ponad dwadzieścia ulepszeń procedur podatkowych, dotyczących rozmaitych aspektów tych procedur ${ }^{61}$. W 1996 r. Kongres przyjął ustawę określaną jako Karta Praw Podatnika II, zawierającą około czterdziestu przepisów, co do zasady odpowiadających

\footnotetext{
${ }^{50}$ The Practical Protection of Taxpayers'..., s. 525, 541.

${ }^{51}$ Ibidem, s. 437.

${ }^{52}$ Ibidem, s. 116; M. Cadesky, I. Hayes, D. Russell, A Model Taxpayer Charter..., s. 73, 75.

${ }^{53}$ M. Cadesky, I. Hayes, D. Russell, A Model Taxpayer Charter..., s. 76.

${ }^{54}$ The Practical Protection of Taxpayers'..., s. 184, 202.

${ }^{55}$ Ibidem, s. 798.

${ }^{56}$ M. Cadesky, I. Hayes, D. Russell, A Model Taxpayer Charte..., s. 162.

${ }^{57}$ The Practical Protection of Taxpayers'..., s. 368.

${ }^{58}$ Ibidem, s. 494.

${ }^{59}$ Ibidem, s. 843 .

${ }^{60}$ Ibidem, s. 232.

${ }^{61}$ Ibidem, s. 842-843.
} 
tym z poprzedniej Karty ${ }^{62}$. W 1998 r. wydano nowe przepisy, które nie noszą nazwy karty praw podatnika ${ }^{63}$, ale są określane jako Karta Praw Podatnika III. W Kartach uregulowano m.in. takie zagadnienia, jak prawo podatnika do nagrywania przesłuchań strony i świadków, zasady oceny pracowników administracji podatkowej, prawo do uzyskania informacji o przysługujących opcjach (alternatywach) proceduralnych dostępnych na różnych etapach procedur administracyjnych, w tym podatkowych ${ }^{64}$. Ponadto w Stanach Zjednoczonych organy podatkowe już od 1988 r. mają obowiązek przygotować komunikat o prawach podatnika i przekazywać go podatnikom przed rozpoczęciem kontroli ${ }^{65}$. W celach informacyjnych czy edukacyjnych administracja podatkowa posługuje się przede wszystkim Publikacją nr 1: Twoje Prawa jako Podatnika ${ }^{66}$, której pierwsza strona jest w istocie Kartą Praw Podatnika. Kopia dokumentu jest przekazywana podatnikowi wraz z zawiadomieniem o kontroli, wraz z korespondencją oraz $\mathrm{w}$ innych sytuacjach, nawet jeśli nie wymaga tego prawo ${ }^{67}$. Wspomniana Karta Praw Podatnika z wykorzystaniem prostych sformułowań wskazuje reguły proceduralne dla kontroli, wymiaru, poboru i zwrotu podatku68. W Karcie wymieniono następujące prawa: prawo do informacji, prawo do usługi o odpowiedniej jakości, prawo do zapłaty prawidłowej kwoty podatku wynikającej z przepisów, prawo do kwestionowania stanowiska organów podatkowych i do bycia wysłuchanym, prawo do zaskarżenia rozstrzygnięć do niezależnego organu, prawo do ostatecznego rozstrzygnięcia sprawy, prawo do prywatności i poufności, prawo do bycia reprezentowanym, prawo do uczciwego i sprawiedliwego systemu podatkowego ${ }^{69}$. Te prawa nie zostały w ten sposób wyrażone we wspominanych ustawach określanych jako Karty Praw Podatnika ${ }^{70}$. Na niektóre z tych praw składa się wiele reguł szczegółowych (np. prawo do ostatecznego rozstrzygnięcia, związane $\mathrm{z}$ instytucją przedawnienia obejmującą wiele przepisów o cha-

\footnotetext{
${ }^{62}$ Ibidem, s. 843 .

${ }^{63}$ Ibidem, s. 845.

${ }^{64}$ Ibidem, s. 843 .

${ }^{65}$ Ibidem.

${ }^{66}$ Ibidem, s. 846.

${ }^{67}$ Ibidem.

${ }^{68}$ Ibidem.
}

${ }^{69}$ Ibidem, s. 846-847. Zob. też Internal Revenue Service, Your Rights as a Taxpayer, Publication 1 (Rev. 9-2017) Catalog Number 64731W, https://www.irs.gov/pub/irs-pdf/ p1.pdf (dostęp: 2.09.2018).

70 The Practical Protection of Taxpayers'..., s. 847. 
rakterze technicznym) ${ }^{71}$. Inne mają charakter aspiracji, dążeń (np. prawo do uczciwego i sprawiedliwego postępowania) ${ }^{72}$. Ponadto administracja podatkowa publikuje inne, bardziej szczegółowe dokumenty dotyczące poszczególnych zagadnień czy praw na poszczególnych etapach postępowania $^{73}$. Dzięki temu sama Karta pozostaje dokumentem krótkim ${ }^{74}$.

Większość Kart w państwach OECD pochodzi od administracji podatkowej i ma charakter niewiążący ${ }^{75}$. P. Baker zauważa, że niekiedy Karta o charakterze deklaracji z czasem przybiera postać normatywną przez zawarcie $\mathrm{w}$ akcie prawnym rangi ustawowej ${ }^{76} . \mathrm{Z}$ ankiety przeprowadzonej przez M. Cadesky'ego, I. Hayesa i D. Russella wśród profesjonalnych pełnomocników z 37 państw członkowskich OECD wynika, że w połowie z tych państw istnieją wątpliwości, czy realne byłoby wprowadzenie Karty o randze ustawowej, posiadającej moc powszechnie obowiązującą ${ }^{77}$.

Niezależnie od mocy prawnej Karty jako minimalny standard wskazuje się pewność, że organy podatkowe w swoich działaniach powinny przestrzegać postanowień Karty, a sądy powinny je ważyć wraz z okolicznościami rozpatrywanej sprawy ${ }^{78}$.

Uwzględniając kryterium zakresu treści, Karty można podzielić na ogólne (kompleksowe), odnoszące się do ogółu praw i obowiązków podatnika obowiązujących we wszystkich rodzajach postępowań w zakresie wszystkich podatków (np. Włochy ${ }^{79}$ ), oraz szczegółowe, regulujące prawa i obowiązki podatnika na etapie postępowania wymiarowego lub kontroli podatkowej (np. Niemcy ${ }^{80}$ ). Kolejnym rodzajem Kart pochodzących od administracji podatkowej są Karty wyznaczające standardy obsługi (service standards), które określają, na jaki standard obsługi podatnicy mogą liczyć w danych warunkach (np. Irlandia ${ }^{81}, \mathrm{RPA}^{82}$ ).

\footnotetext{
${ }^{71}$ Ibidem.

${ }^{72}$ Ibidem.

${ }^{73}$ Zob. ibidem.

${ }^{74}$ Ibidem.

${ }^{75}$ Ibidem, s. 75.

76 P. Baker, Taxpayers' Charters..., s. 133.

${ }^{77}$ M. Cadesky, I. Hayes, D. Russell, A Model Taxpayer Charter..., s. 150.

${ }^{78}$ P. Baker, Taxpayers' Charters..., s. 133.

${ }^{79}$ Ibidem, s. 437.

${ }^{80}$ The Practical Protection of Taxpayers'..., s. 373, 397.

${ }^{81}$ M. Cadesky, I. Hayes, D. Russell, A Model Taxpayer Charter..., s. 74-75.

${ }^{82}$ The Practical Protection of Taxpayers'..., s. 685, 703.
} 
Można też dokonywać klasyfikacji Kart według kryterium wyodrębnienia. Karty występują jako odrębne, niezależne dokumenty normatywne (np. Meksyk ${ }^{83}$, Włochy ${ }^{84}$ ) lub deklaratywne (np. Australia ${ }^{85}$ ) oraz, niekiedy, jako rozdziały w ordynacjach podatkowych czy kodeksach podatkowych (np. Chile ${ }^{86}$ ). Niektóre państwa poprzestają na zawarciu kilku podstawowych praw w ustawach dotyczących procedury podatkowej, w jednym (np. Kolumbia ${ }^{87}$, Ukraina ${ }^{88}$ ) lub kilku następujących po sobie przepisach (np. Tajwan ${ }^{89}$, Kolumbia ${ }^{90}$, Peru ${ }^{91}$ ). Stopień wyodrębnienia przepisów regulujących prawa podatnika w systematyce wewnętrznej aktu prawnego, wprowadzenie odrębnego tytułu wskazującego na zawartość tej jednostki redakcyjnej, może istotnie oddziaływać na funkcjonowanie tych przepisów jako autentycznej Karty Praw Podatnika, szczególnie w kontekście tego, jak ważna jest świadomość społeczna istnienia i funkcjonowania Karty.

Trend konsolidacji normatywnej regulacji praw podatnika prowadzi albo do przyjęcia Karty jako odrębnego dokumentu normatywnego (np. Meksyk ${ }^{92}$ ), albo do zgrupowania przepisów dotyczących tej materii $\mathrm{w}$ jednym przepisie, kilku następujących po sobie przepisach czy wyodrębnionym rozdziale ogólnej ustawy podatkowej (np. Chile ${ }^{93}$ ), przy czym przepisy wcześniej obowiązujące mogą pozostać także w dotychczasowych aktach. Niekiedy zdarza się jednak, że przepisy zawarte w odrębnej ustawie stanowiącej Kartę z czasem ulegają modyfikacjom i przenoszone są do innych ustaw ogólnego prawa podatkowego, a sama Karta jako jednolity akt przestaje obowiązywać (np. Belgia ${ }^{94}$ ). W latach 1998-2004 w Hiszpanii obowiązywała ustawa określana mianem „Ustawy podatnika” i zawierająca wiele podstawowych praw podatnika ${ }^{95}$. W 2004 r. ustawa ta przestała jednak obowiązywać, a jej wszystkie przepisy dotyczące praw podatnika

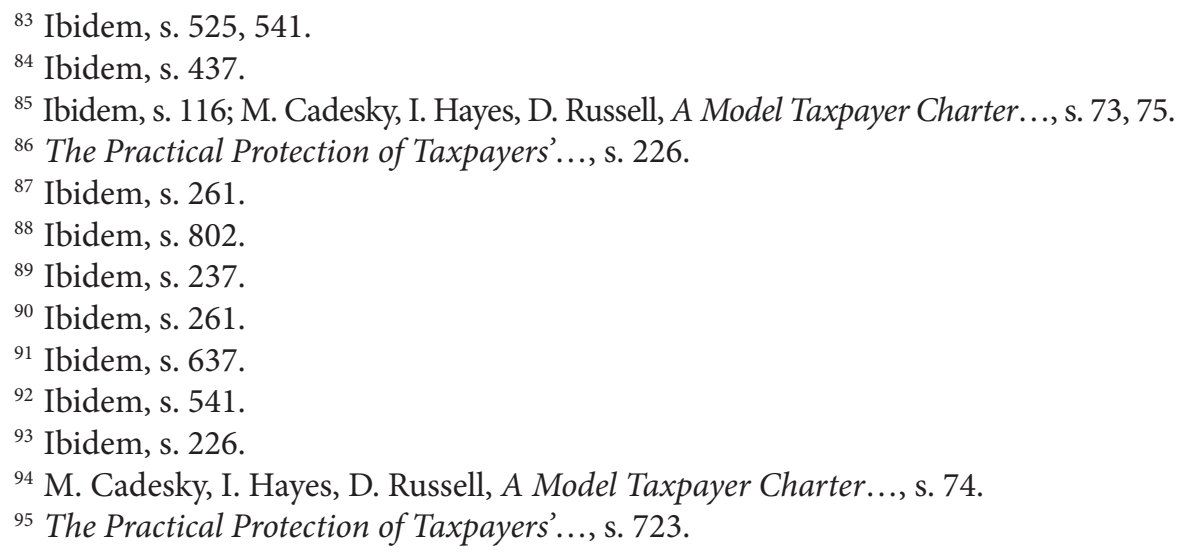


przeniesiono do jednego artykułu ordynacji podatkowej ${ }^{96}$. Odrębna Karta została więc zastąpiona przepisami stanowiącymi część ordynacji podatkowej.

W państwach federacyjnych występują karty na poziomie stanowym (np. Brazylia ${ }^{97}$, USA $^{98}$ ) i karty na poziomie federalnym (np. Meksyk ${ }^{99}$, $\mathrm{USA}^{100}$ ). W niektórych państwach również na poziome lokalnym (gminnym) dochodzi do przyjęcia karty (np. Brazylia ${ }^{101}$ ). M. Cadesky, I. Hayes i D. Russell zwracają uwagę, że Karta o charakterze ogólnym powinna być przestrzegana także przez samorządowe organy podatkowe ${ }^{102}$.

\section{TREŚĆ, STOPIEŃ SZCZEGÓ£OWOŚCI I SPOSÓB SFORMUŁOWANIA}

Kart Praw Podatnika

Warto zwrócić uwagę, że wiele Kart zawiera odniesienie jednocześnie do praw i obowiązków podatników, posługiwanie się określeniem „Karta Praw Podatnika” jest zatem pewnym uproszczeniem, skrótem myślowym. Prawom podatników odpowiadają obowiązki organów podatkowych, a prawom organów podatkowych - obowiązki podatników. Karty można więc uznać za przejaw poszukiwania równowagi między prawami i obowiązkami podatników oraz administracji podatkowej. Jak zauważa P. Baker, historycznie Karty określały prawa podatników, ich najnowsze wersje dotyczą zaś zarówno praw, jak i obowiązków w dążeniu do pewnej równowagi ${ }^{103}$. Przykładowo, Karta australijska z 1997 r. zawiera trzydzieści praw i sześć obowiązków ${ }^{104}$.

Umieszczenie w Karcie jednocześnie praw i obowiązków wzmacnia przekaz, że podatnikom przysługują określone prawa, ale że nie mogą oni też zapominać o swoich obowiązkach ${ }^{105}$. Fakt, że Karta dotyczy zarówno praw, jak i obowiązków, warto podkreślić w tytule dokumentu, tak jak

${ }^{96}$ Ibidem, s. 723-724; M. Cadesky, I. Hayes, D. Russell, A Model Taxpayer Charter..., s. 74 .

97 The Practical Protection of Taxpayers'..., s. 182.

${ }^{98}$ Ibidem, s. 707.

${ }^{99}$ Ibidem, s. 525, 541.

${ }^{100}$ Ibidem, s. 723.

${ }^{101}$ Ibidem, s. 182.

102 M. Cadesky, I. Hayes, D. Russell, A Model Taxpayer Charter..., s. 36.

${ }^{103}$ P. Baker, Taxpayers' Charters..., s. 133.

${ }^{104}$ Ibidem, s. 134-135.

${ }^{105}$ M. Cadesky, I. Hayes, D. Russell, A Model Taxpayer Charter..., s. 21. 
zrobili to M. Cadesky, I. Hayes i D. Russell ${ }^{106}$. Autorzy ci wskazują również, że postanowienia Karty nie powinny być stosowane wybiórczo, z założenia bowiem dopiero razem tworzą pewien zrównoważony układ ${ }^{107}$.

M. Cadesky, I. Hayes i D. Russell zauważyli też, że Karta nie powinna pomijać zagadnienia praw i obowiązków doradców podatkowych, którzy są ważną częścią systemu podatkowego ${ }^{108}$. Zwrócili ponadto uwagę, iż „złożoność systemów podatkowych powoduje, że podatnicy ze skomplikowanymi sprawami finansowymi powinni korzystać z pomocy doradców podatkowych, tak jak pacjenci poszukują pomocy lekarzy, zamiast stawiać autodiagnozę i stosować domowe sposoby leczenia"109.

Jak wskazuje się w doktrynie, w Karcie powinny być uregulowane zarówno prawa i obowiązki proceduralne, jak i materialnoprawne, szczególnie że niekiedy trudno wytyczyć granicę między regulacją proceduralną i materialnoprawną ${ }^{110}$. W Karcie może się znaleźć materialnoprawne zapewnienie, że prawo podatkowe nie będzie działało wstecz, oraz proceduralne zapewnienie, że będzie respektowane prawo podatnika do bycia reprezentowanym przez profesjonalnych pełnomocników. Można zauważyć, że w Kartach o charakterze niewiążącym proporcjonalnie większą wagę przywiązuje się do takich zagadnień, jak standardy usług administracji podatkowej, zobowiązanie do uprzejmego traktowania, zobowiązanie do szybkiego czy efektywnego załatwiania spraw ${ }^{111}$.

Powszechnie uważa się, że Karta powinna znajdować zastosowanie do wszystkich podatków, a nie tylko wybranych, np. podatków dochodowych $^{112}$. Zwraca się też uwagę na konieczność stosowania Karty zarówno do podatków państwowych czy federalnych, jak i do podatków stanowych czy lokalnych (samorządowych), choćby to wymagało przyjęcia tej samej karty przez ciała prawodawcze różnych poziomów, od państwowego (federalnego) po lokalny (samorządowy ${ }^{113}$. Wybiórcze stosowanie Karty mogłoby naruszać zasadę równości oraz zasady uczciwej konkurencji ${ }^{114}$.

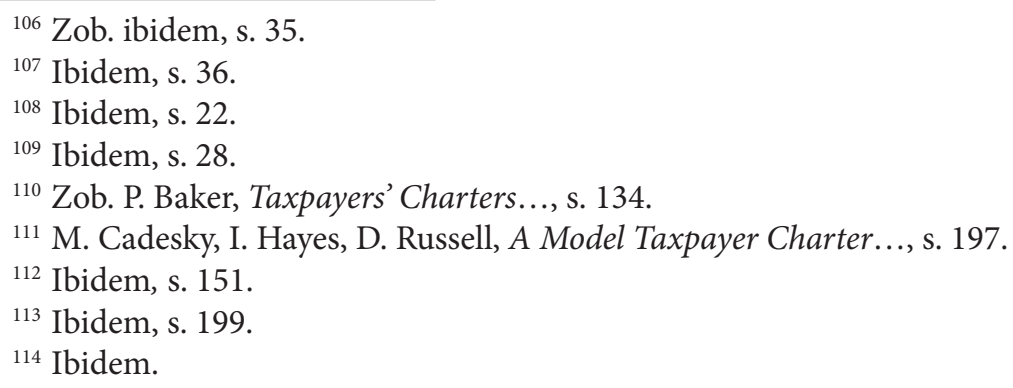


Język kart i stopień ich szczegółowości jest bardzo różny. Karta powinna być napisana w języku zrozumiałym dla ogółu społeczeństwa ${ }^{115}$. Nie może być dokumentem technicznym, wykorzystującym hermetyczny język prawa podatkowego. Ze względu na nieodłączne cechy języka prawnego i wymogi prawidłowej legislacji Karta o charakterze normatywnym będzie jednak bardziej zachowawcza pod względem językowym, nieco mniej komunikatywna niż karta w konwencji deklaratywnej, broszurowej, która może zawierać zwroty potoczne, bezpośrednie (np. Australia ${ }^{116}$, USA $^{117}$ ).

Nie wydaje się konieczne ani wskazane konstruowanie tak obszernych, szczegółowych Kart, jak proponują M. Cadesky, I. Hayes i D. Russell, którzy stworzyli Modelowa Kartę o objętości ponad trzydziestu stron ${ }^{118}$. Wprawdzie autorzy ci twierdzą, że Karta dla swej efektywności musi być dostatecznie szczegółowa, bo zbyt ogólne sformułowania dotyczące praw podatnika mogą sprawiać trudności w zakresie ich wykładni i egzekwowania ${ }^{119}$, jednak przyjęcie nadmiernie rozbudowanej Karty mogłoby stanowić zaprzeczenie jej idei. Aby karta zachowywała swój walor wysokiej komunikatywności, nie może być dokumentem kilkunasto- czy kilkudziesięciostronicowym, nieróżniącym się od innych aktów prawa podatkowego. Dokonując wyboru między wersją jedynie hasłową a wersją proponowaną przez powyżej wskazanych autorów, należy opowiedzieć się raczej za tą pierwszą. Lepszym rozwiązaniem od proponowanego przez M. Cadesky’ego, I. Hayesa i D. Russella, choć nadal dość rozbudowanym, wydaje się to zawarte w $W y$ tycznych dotyczących wzoru Kodeksu podatników Unii Europejskiej.

Odpowiedzią może też być forma hybrydowa, hasłowa (z precyzyjnie sformułowanym prawem czy obowiązkiem i potocznie sformułowanym komentarzem do hasła). P. Baker wskazuje na możliwość wykorzystania nowoczesnych technologii: publikowanie w Internecie względnie zwięźle sformułowanych Kart, zaopatrzonych w linki do bardziej szczegółowych źródeł wyjaśniających treść i znaczenie poszczególnych postanowień Karty ${ }^{120}$. Taka Karta mogłaby mieć formę hasłową (nagłówkową), a powiązane z poszczególnymi nagłówkami dokumenty mogłyby zawierać szczegółowe wyjaśnienia, w tym odniesienia do praktycznych aspektów danego prawa

\footnotetext{
${ }^{115}$ P. Baker, Taxpayers' Charters..., s. 132.

116 The Practical Protection of Taxpayers'..., s. 116.

${ }^{117}$ Ibidem, s. 846.

118 Zob. M. Cadesky, I. Hayes, D. Russell, A Model Taxpayer Charter..., s. 35-71.

119 Ibidem, s. 199.

${ }^{120}$ P. Baker, Taxpayers' Charters..., s. 133.
} 
czy obowiązku. Można by również uzupełnić Kartę dokumentami wyjaśniającymi jej zastosowanie do poszczególnych kategorii podatników (osób fizycznych, osób prawnych, przedsiębiorców) ${ }^{121}$.

Karta nie może być zbyt ogólna, ale nie może też być zbyt szczegółowa. Trzeba odpowiednio wyważyć jej zawartość, pamiętając, że najczęściej Karta powtarza treść normatywną innych przepisów, które zawierają regulację znacznie bardziej szczegółową.

Wymóg, aby Karta nie była dokumentem zbyt obszernym, można także sformułować w nawiązaniu do samego słownikowego rozumienia określenia „karta”. Zgodnie z internetowym Słownikiem Jezzyka Polskiego PWN „karta” to „kawałek papieru z nadrukiem, przeznaczony do wpisywania różnych informacji”, „część składowa książki, zeszytu, czasopisma itp., obejmująca dwie stronice" 122 . Chodzi zatem o kawałek papieru zapisany treścią, podstawowymi prawami i obowiązkami podatnika, a nie obszerną broszurę dotyczącą tych zagadnień. W Słowniku wskazano również, że „karta” może być rozumiana jako „deklaracja dotycząca praw i przywilejów jakiejś grupy społecznej lub zawodowej, wspólnego programu działania itp." ${ }^{23}$.

\section{Kontrola przestrzegania postanowień Karty Praw Podatnika} I OKRESOWY PRZEGLĄD TREŚCI KARTY

Należy zgodzić się z P. Bakerem, że samo stworzenie i ogłoszenie Karty nie jest wystarczające ${ }^{124}$. Konieczna jest kontrola jej przestrzegania. Dla skuteczności Karty, także tej pośredniej, ważne jest, by administracja podatkowa była rozliczana z przestrzegania postanowień Karty.

Kontrola przestrzegania Karty powinna przyjmować zarówno formę indywidualną, jak i ogólną.

W ramach kontroli indywidualnej w przypadku naruszenia postanowień Karty podatnik powinien dysponować możliwością złożenia skargi ${ }^{125}$. Procedury składania i rozpatrywania takich skarg powinny być uregulowane i zakomunikowane podatnikowi, tak by miał on świadomość takiej możliwości, wiedział, do kogo zwrócić się ze swoim problemem, i wierzył,

${ }^{121}$ Ibidem, s. 134.

122 https://sjp.pwn.pl/slowniki/karta.html (dostęp: 7.11.2017).

${ }^{123}$ Ibidem.

${ }^{124}$ P. Baker, Taxpayers' Charters..., s. 133.

${ }^{125}$ M. Cadesky, I. Hayes, D. Russell, A Model Taxpayer Charter..., s. 25. 
że jego skarga zostanie rzeczywiście rozpatrzona. Stwierdzenie naruszenia powinno skutkować odpowiedzialnością urzędnika lub instytucji, które naruszenia się dopuściły.

Ważną rolę w zakresie kontroli zarówno ogólnej, jak i indywidualnej mogą odegrać takie instytucje, jak Rzecznik Praw Obywatelskich, Rzecznik Praw Podatnika i Adwokat Podatnika. Jednakże M. Cadesky, I. Hayes i D. Russell podają w wątpliwość skuteczność tych organów, o ile nie posiadają one prawnych możliwości egzekwowania postanowień Karty ${ }^{126}$. Kontrola ogólna mogłaby też należeć do takich instytucji, jak Najwyższa Izba Kontroli. Ewentualnie można rozważyć parlamentarną kontrolę nad administracją podatkową w tym zakresie. W ramach kontroli ogólnej (monitoringu) przydatne mogą być również badania sondażowe dotyczące opinii samych podatników i ich doradców podatkowych o poziomie poszanowania praw w praktyce (np. Zjednoczone Królestwo ${ }^{127}$ ). Kontrola ogólna odegrała bardzo ważną rolę w Australiii ${ }^{128}$.

Należy też okresowo dokonywać przeglądu Karty, by wprowadzać potrzebne ulepszenia, podążać za nowymi, coraz lepszymi standardami. Doświadczenia wielu państw (np. Australia ${ }^{129}$, USA $^{130}$, Zjednoczone Królestwo ${ }^{131}$ ) potwierdzają konieczność i zasadność wprowadzania zmian w kartach.

\section{Efektywność Karty Praw Podatnika w ocenie praktyków}

Zasadniczą kwestią jest stwierdzenie, czy Karta rzeczywiście może poprawić relacje między organami podatkowymi a podatnikami ${ }^{132}$, zwiększając stopień poszanowania praw tych drugich. Ważne jest, by Karta nie dawała fałszywego wrażenia co do praktycznej doniosłości poszczególnych praw i obowiązków podatnika ${ }^{133}$.

Jak zauważyli M. Cadesky, I. Hayes i D. Russell, spośród siedemnastu ankietowanych państw członkowskich OECD posiadających Kartę tylko w przypadku trzech państw respondenci kategorycznie stwierdzili,

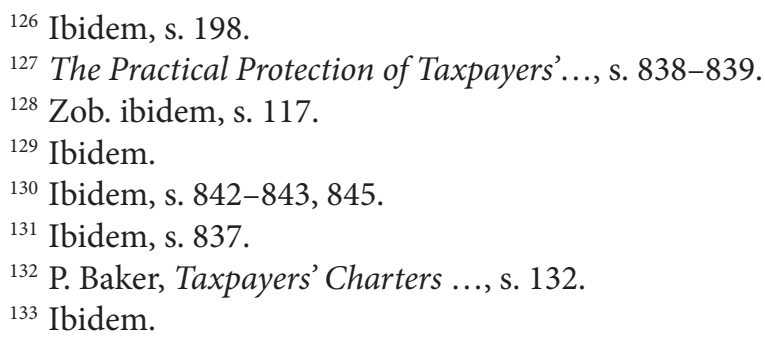


że postanowienia Karty są zawsze przestrzegane ${ }^{134}$. W ośmiu państwach organy podatkowe w pewnym zakresie przestrzegają Karty (np. Kanada), a w sześciu - często nie przestrzegają (np. Australia) ${ }^{135}$. W odniesieniu do niektórych państw, od niedawna dysponujących Kartą, na ocenę praktyki było zbyt wcześnie (np. Malta) ${ }^{136}$. W odniesieniu do Kanady zauważono, że wiele zasad jest przestrzeganych, ale trudno stwierdzić, czy ze względu na zawarcie tych zasad w Karcie, czy raczej wobec faktu, że dane prawo, np. prawo do prywatności, jest też wyrażone w ustawie podatkowej ${ }^{137}$. Natomiast praktyczna realizacja wymienionego w Karcie prawa do otrzymania wyczerpujących, prawidłowych, jasnych informacji na czas wygląda różnie ${ }^{138}$.

Profesjonalni pełnomocnicy z niewielu państw (5 z 37 ankietowanych) uznają Kartę za ważną podstawę kształtującą relacje z administracją podatkową ${ }^{139}$. W niektórych państwach (5 z 37) Karta „jest nieco wykorzystywana” ${ }^{140}$. Pełnomocnicy sięgają po postanowienia Karty głównie podczas kontroli podatkowej oraz występując o anulowanie czy redukcję kar (np. we Włoszech doktryna dobrej wiary jest wykorzystywana jako podstawa wniosków o redukcję kar) ${ }^{141}$. Karta jest także wykorzystywana, aby pozyskać informacje o toczącym się postępowaniu (np. w Kanadzie) ${ }^{142}$. We Francji Karta dla kontroli podatkowej jest podstawą do żądania spotkania z przełożonym kontrolującego ${ }^{143}$. Zdaniem rumuńskiego sprawozdawcy pełnomocnicy profesjonalni mogą nawet nie mieć świadomości istnienia Karty ${ }^{144}$. Również zdaniem sprawozdawcy bułgarskiego Karta nie jest instrumentem popularnym wśród profesjonalnych pełnomocników ${ }^{145}$. Natomiast w Australii, we Francji, na Malcie i w Zjednoczonym Królestwie Karta jest uważana za ważny instrument, przy czym sprawozdawca brytyjski podkreśla,

\footnotetext{
${ }^{134}$ M. Cadesky, I. Hayes, D. Russell, A Model Taxpayer Charter..., s. 75.

${ }^{135}$ Ibidem.

${ }^{136}$ Ibidem.

137 Ibidem.

${ }^{138}$ Ibidem.

139 Ibidem, s. 76.

${ }^{140}$ Ibidem.

${ }^{141}$ Ibidem.

142 Ibidem.

${ }^{143}$ Ibidem.

${ }^{144}$ Zob. ibidem, s. 77.

${ }^{145}$ Ibidem.
} 
że Karta służy głównie podatnikom niekorzystającym z usług profesjonalnych pełnomocników ${ }^{146}$.

Profesjonalni pełnomocnicy z 19 spośród 37 państw wyraźnie stwierdzili, że popierają ideę Karty posiadającej moc prawną, a więc wiążącej dla administracji podatkowej, a przedstawiciele 6 państw, że wystarczająca byłaby niewiążąca Karta pochodząca od administracji podatkowej, ale przez tę administrację przestrzegana ${ }^{147}$. Sprawozdawcy austriacki i holenderski ocenili, że prawa są dostatecznie gwarantowane dzięki obowiązującym przepisom, a Karta nie jest potrzebna ${ }^{148}$. Jednocześnie, jak już wskazano, z ankiety przeprowadzonej przez M. Cadesky'ego, I. Hayesa i D. Russella wynika, że w połowie z 37 badanych państw istnieją wątpliwości, czy realne byłoby wprowadzenia Karty o randze ustawowej, posiadającej moc powszechnie obowiązującą ${ }^{149}$.

Ogólna ocena Karty jako narzędzia ochrony praw podatnika jest jednak bardzo korzystna: właściwie respondenci ze wszystkich 37 badanych państw stwierdzili, że jest to narzędzie dobre i potrzebne ${ }^{150}$. Nie można też pomijać potencjalnego wpływu karty na poziom przestrzegania prawa (voluntary compliance), dobrowolnej realizacji zarówno samych zobowiązań podatkowych, jak i towarzyszących im obowiązków instrumentalnych. Jak już wskazywano, poziom ten zależy bowiem od stopnia zaufania podatników do systemu podatkowego, od tego, czy są „przekonani" do tego systemu ${ }^{151}$.

Niepokoić może tylko pewne spostrzeżenie poczynione przez M. Cadesky'ego, I. Hayesa i D. Russella. Z przeprowadzonej przez nich ankiety wynika, że podatnicy, a szczególnie ci, którzy nie korzystają z usług profesjonalnych pełnomocników, często nie mają świadomości, że istnieje taki dokument jak Karta ${ }^{152}$. Aby Karta mogła spełnić swoją rolę, należy więc prowadzić odpowiednie akcje informacyjne, należy edukować zarówno podatników, jak i administrację podatkową o istnieniu Karty, jej statusie prawnym, treści i znaczeniu poszczególnych postanowień. Taką edukację można obecnie prowadzić niskim kosztem, $\mathrm{z}$ wykorzystaniem nowoczesnych

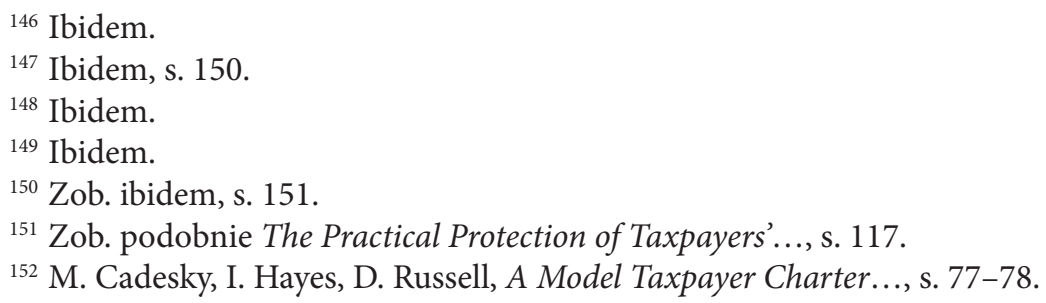


form komunikacji za pośrednictwem Internetu. Karta może także stanowić doskonały materiał edukacyjny dla młodzieży szkolnej. Skierowanie takiego przekazu podatkowego do młodzieży na odpowiednio wczesnym etapie edukacji może zaprocentować powstaniem nowej grupy podatników, świadomych swoich praw i jednocześnie obowiązków, podatników, dla których te prawa i obowiązki w realiach społeczeństwa obywatelskiego byłyby czymś naturalnym. Oczywiście, konieczne jest też przekazywanie podatnikowi egzemplarza Karty przy wszczęciu kontroli czy postępowania podatkowego.

9. Forma, treść i rola Karty Praw Podatnika W WARUNKACH POLSKIEGO SYSTEMU PODATKOWEGO

Karta Praw Podatnika jest stosunkowo nowym, ale dość powszechnie występującym instrumentem ochrony praw podatnika, który stopniowo staje się międzynarodowym standardem. Z tego względu brak Karty w Polsce należy ocenić negatywnie, jako przejaw nienadążania za najlepszymi praktykami. Również występujące w Polsce w ostatnich latach liczne i częste zmiany w prawie podatkowym, niekiedy zagrażające prawom podatnika, a także nadal stwierdzane naruszenia praw podatnika w procesie stosowania prawa stanowią istotne argumenty przemawiające za wprowadzeniem do polskiego systemu podatkowego Karty, jako nowego instrumentu wzmacniającego ochronę tych praw zarówno na etapie tworzenia, jak i stosowania prawa podatkowego.

Posiadanie Karty może nie tylko podnieść poziom praktycznej ochrony praw podatnika, w tym przez zwiększenie wśród podatników świadomości przysługujących im praw, a wśród przedstawicieli administracji skarbowej przeświadczenia o konieczności poszanowania tych praw, ale także zwiększyć społeczną akceptację systemu podatkowego, a zatem i poziom dobrowolnej realizacji obowiązków podatkowych, szczególnie jeśli Karta będzie też regulowała standardy dla tworzenia prawa podatkowego, skutkujące lepszym wyważeniem interesu podatników i interesu wierzyciela podatkowego. Posiadanie Karty może ponadto poprawić ocenę polskiego systemu podatkowego na tle konkurencyjnych jurysdykcji podatkowych.

Choć za granicą Karty częściej przybierają postać deklaracji pochodzącej od administracji podatkowej niż przepisów prawa powszechnie obowiązującego ustanowionych przez władzę ustawodawczą, Karty o charakterze normatywnym uważane są za znacznie skuteczniejsze. Dlatego 
bardziej wskazane byłoby przyjęcie w Polsce Karty w formie ustawowej. Oddziaływanie takiej Karty na praktykę podatkową byłoby z pewnością większe. Nie należy też zapominać, że tylko forma ustawowa, jako pewnego rodzaju samozwiązanie się prawodawcy, dałaby szansę na poprawę praktyki tworzenia prawa podatkowego. Jednostronna deklaracja administracji podatkowej nie mogłaby poprawić sytuacji w tym zakresie. W tym kontekście warto też zauważyć, że polska administracja podatkowa opublikowała swoistą deklarację praw i obowiązków podatnika ${ }^{153}$, deklaracja ta nie ma jednak żadnego określonego waloru prawnego, a podatnicy w dużej mierze nie mają świadomości jej istnienia.

Aby Karta przyjęta w formie ustawy nie podzieliła losu polskiej deklaracji oraz niektórych zagranicznych Kart, które „umknęły” uwadze podatników, a nawet pełnomocników profesjonalnych, konieczne byłoby prowadzenie szeroko zakrojonej akcji edukacyjnej skierowanej do podatników, ich służb podatkowo-księgowych oraz administracji skarbowej. Należałoby informować społeczeństwo o istnieniu Karty, jej statusie prawnym, treści i znaczeniu poszczególnych postanowień. Należałoby również wprowadzić bezwzględny obowiązek przekazywania podatnikowi egzemplarza Karty przy wszczęciu kontroli czy postępowania podatkowego, tak jak praktykuje się w wielu państwach.

Pewną wadą proponowanej formy ustawowej w porównaniu $\mathrm{z}$ formą deklaracji może się okazać nieco mniejsza zrozumiałość, wynikająca z konieczności zachowania reguł języka prawnego oraz techniki legislacyjnej. Częściowym rozwiązaniem tego problemu mogłoby być nałożenie na administrację podatkową obowiązku publikowania i przekazywania podatnikom, wraz z egzemplarzem Karty, informatorów w sposób uproszczony przekazujących treść Karty, tak jak poczyniono w kilku państwach.

W pracach nad treścią przyszłej Karty zasadne byłoby wykorzystanie dotychczasowego dorobku, szczególnie zaś Deklaracji Praw Podatnika podpisanej 18 maja 2011 r. pod patronatem Krajowej Rady Doradców Podatkowych ${ }^{154}$, gdyż dokument ten opracowali wspólnie przedstawiciele wielu środowisk zainteresowanych prawem podatkowym (sędziowie,

${ }^{153}$ Ministerstwo Finansów, Uprawnienia i obowiązki podatnika, http://www.finanse. mf.gov.pl/abc-podatkow/uprawnienia-i-obowiazki-podatnika (dostęp: 18.01.2018).

${ }^{154}$ Zob. W. Konieczny, S. Babiarz, B. Dauter, B. Brzeziński, P. Karwat, T. Michalik, A. Olesińska, D. Szczygieł, D. Szubielska, Deklaracja Praw Podatnika, podpisana przez szerokie grono przedstawicieli nauki i praktyki prawa podatkowego w dniu 18 maja 2011 r. podczas Dnia Ochrony Praw Podatnika w Warszawie, https://krdp.pl//aktualnosciall.php/9/1643 (dostęp: 18.01.2018). 
doradcy podatkowi, naukowcy). Można by też sięgnąć do projektów przedstawianych na przestrzeni lat przez poszczególnych przedstawicieli polskiej nauki i praktyki prawa podatkowego ${ }^{155}$. Aby dać wyraz dążeniu do zgodności z międzynarodowymi standardami i najlepszymi praktykami, należałoby też sięgnąć do rezultatów prac międzynarodowych, w tym Modelowej Karty Podatnika i Wytycznych dotyczacych wzoru Kodeksu podatników Unii Europejskiej. Wreszcie, można by wykorzystać dorobek Komisji Kodyfikacyjnej Ogólnego Prawa Podatkowego, która podjęła próbę włączenia postanowień typowych dla Kart do treści Ordynacji podatkowej ${ }^{156}$.

Normy zawarte w Karcie powinny być projektowane z dużą ostrożnością, z uwzględnieniem ich założonej przyszłej roli jako zasad systemu prawa podatkowego, czyli norm o szczególnej doniosłości w całym systemie prawa podatkowego, stosowanych samodzielnie lub wspólnie z innymi normami, stanowiących kontekst interpretacyjny dla całego systemu prawa podatkowego. Z istoty swej powinny być bardziej ogólne niż te zawarte w Ordynacji podatkowej i innych ustawach, które stanowiłyby ich uszczegółowienie. Co do zasady rolą Karty nie powinno być przyznanie podatnikom nowych praw, bo w polskim systemie podatkowym w większości wynikają już one z Konstytucji, Ordynacji podatkowej i z ustaw szczegółowych prawa proceduralnego i materialnego. Karta wzmocniłaby ochronę tych praw podatnika, tworząc pewną nową jakość w stosunkach między podatnikami a organami podatkowymi, skodyfikowaną w postaci jednolitego dokumentu, sformułowanego w możliwie przystępny sposób, łatwo dostępnego i stanowiącego trwały element świadomości społecznej. Nie wyklucza to jednak możliwości uzupełnienia Kartą obecnego katalogu praw podatnika, jeśli w toku prac zostanie stwierdzona taka potrzeba, albo wyrażenia w Karcie wprost praw, których obowiązywanie obecnie bywa kwestionowane przez organy podatkowe (np. domniemanie dobrej wiary podatnika).

${ }^{155}$ Zob. A. Mariański, Projekt Deklaracji Praw Podatnika, Oficyna Prawa Polskiego, www.pit.pl/att/Projekty_Karty_Praw_Podatnika.doc (dostęp: 18.01.2018); D. Szubielska, Projekt Karty Praw Podatnika, Oficyna Prawa Polskiego, www.pit.pl/att/Projekty_Karty_ Praw_Podatnika.doc (dostęp: 18.01.2018); T. Dębowska-Romanowska, Projekt Karty Praw Uczciwego Podatnika, Oficyna Prawa Polskiego, www.pit.pl/att/Projekty_Karty_ Praw_Podatnika.doc (dostęp: 18.01.2018); CDiSP, Projekt przepisów ogólnych Ordynacji Podatkowej, „Kwartalnik Prawa Podatkowego” 2001, nr 3-4.

${ }^{156}$ Zob. Komisja Kodyfikacyjna Ogólnego Prawa Podatkowego, Projekt z dnia 6 października 2017 r. ustawy Ordynacja podatkowa, art. 14-34, http://www.mf.gov.pl/ ministerstwo-finansow/dzialalnosc/ciala-kolegialne/komisja-kodyfikacyjna-ogolnegoprawa-podatkowego/prace-komisji (dostęp: 18.01.2018). 


\section{BiBLIOGRAFIA}

Baker P., Taxpayers' Charters and a Taxpayers' Charter for Europe, [w:] Protection of Taxpayer's Rights. European, International and Domestic Tax Law Perspective, red. W. Nykiel, M. Sęk, Wolters Kluwer Polska, Warszawa 2009.

Bevacqua J., Redressing the Imbalance: Challenging the Effectiveness of the Australian Taxpayers' Charter, „Australian Tax Forum” 2013, no. 28.

Cadesky M., Hayes I., Russell D., A Model Taxpayer Charter. Preliminary Report. Towards Greater Fairness in Taxation, AOTCA, CFE, STEP, London 2013.

CDiSP, Projekt przepisów ogólnych Ordynacji Podatkowej, „Kwartalnik Prawa Podatkowego" 2001, nr 3-4.

Cerioni L., The Possible Introduction of a European Taxpayer Code: Objectives and Potential Alternatives, „European Taxation” 2014, no. 9.

Dębowska-Romanowska T., Projekt Karty Praw Uczciwego Podatnika, Oficyna Prawa Polskiego, www.pit.pl/att/Projekty_Karty_Praw_Podatnika.doc (dostęp: 18.01.2018).

Komisja Europejska, Wytyczne dotyczące wzoru Kodeksu podatników Unii Europejskiej, Bruksela, 2016 r., https://ec.europa.eu/taxation_customs/sites/taxation/files/guidelines_for_a_model_for_a_european_taxpayers_code_pl.pdf (dostęp 7.11.2017).

Komisja Kodyfikacyjna Ogólnego Prawa Podatkowego, Projekt z dnia 6 października 2017 r. ustawy Ordynacja podatkowa, art. 14-34, http://www.mf.gov.pl/ministerstwofinansow/dzialalnosc/ciala-kolegialne/komisja-kodyfikacyjna-ogolnego-prawapodatkowego/prace-komisji (dostęp: 18.01.2018).

Konieczny W., Babiarz S., Dauter B., Brzeziński B., Karwat P., Michalik T., Olesińska A., Szczygieł D., Szubielska D., Deklaracja Praw Podatnika, podpisana przez szerokie grono przedstawicieli nauki i praktyki prawa podatkowego w dniu 18 maja $2011 \mathrm{r}$. podczas Dnia Ochrony Praw Podatnika w Warszawie, https://krdp.pl//aktualnosciall.php/9/1643 (dostęp: 18.01.2018).

Mariański A., Projekt Deklaracji Praw Podatnika, Oficyna Prawa Polskiego, www.pit.pl/ att/Projekty_Karty_Praw_Podatnika.doc (dostęp: 18.01.2018).

OECD, GAP002 Taxpayers' Rights and Obligations - Practice Note, Paris 2003.

OECD, Taxpayers' Rights and Obligations: A survey of the legal situation in OECD countries, Paris 1990.

Opałek K., Wróblewski J., Zagadnienia teorii prawa, PWN, Warszawa 1969.

The Practical Protection of Taxpayers' Fundamental Rights, red. P. Baker, P. Pistone, Cahiers de droit fiscal international vol. 100b, Sdu Uitgevers, Hague 2015.

Szubielska D., Projekt Karty Praw Podatnika, Oficyna Prawa Polskiego, www.pit.pl/att/ Projekty_Karty_Praw_Podatnika.doc (dostęp: 18.01.2018).

Wróblewski J., Prawo obowiazujące a „ogólne zasady prawa”, „Zeszyty Naukowe Uniwersytetu Łódzkiego. Nauki Humanistyczno-Społeczne. Seria I" 1965, z. 42.

Wróblewski J., Sądowe stosowanie prawa, PWN, Warszawa 1972. 


\section{The Charter of Taxpayer's Rights in the Polish tax system}

IN THE LIGHT OF FOREIGN EXPERIENCE

Summary. The purpose of the article is not to discuss the form and content of the Charters of axpayer's Rights in individual countries, but to make some generalizations based on the analysis of solutions functioning in different legal systems and proposed as part of international initiatives aimed at dissemination and unification of the Charter concept. These generalizations will be the basis for formulating, at the end of the article, preliminary conclusions regarding the possible role, form and content that the Charter could adopt in the circumstances of the Polish tax system.

Keywords: taxpayer's rights, taxpayer's protection, Charter of Taxpayer's Rights 